\title{
Erythropoietin in the critically ill: do we ask the right questions?
}

\author{
Oscar McCook', Michael Georgieff', Angelika Scheuerle², Peter Möller², Christoph Thiemermann³ \\ and Peter Radermacher,**
}

\begin{abstract}
There is a plethora of experimental data on the potential therapeutic benefits of recombinant human erythropoietin (rhEPO) and its synthetic derivatives in critical care medicine, in particular in ischemia/ reperfusion injury. Most of the recent clinical trials have not shown clear benefits, and, in some patients, EPOaggravated morbidity and mortality was even reported. Treatment with rhEPO has been successfully used in patients with anemia resulting from chronic kidney disease, but even a subset of this patient population does not adequately respond to rhEPO therapy. The following viewpoint uses rhEPO as an example to highlight the possible pitfalls in current practice using young healthy animals for the evaluation of therapies to treat patients of variable age and underlying chronic co-morbidity.
\end{abstract}

\section{Introduction}

The potential therapeutic benefits of recombinant human erythropoietin (rhEPO) and its synthetic derivatives in critical care medicine have recently been reviewed in various journals [1-3] and even occasioned impassioned correspondences $[4,5]$. The results of pre-clinical trials suggest that rhEPO could be used not only to ameliorate anemia, but also to limit organ injury/dysfunction associated with stroke, myocardial infarction, trauma, hemorrhage and sepsis. However, despite the promising pre-clinical results, most recent clinical trials have not shown clear benefits, and, in some patients, EPO-aggravated morbidity and mortality was even reported. Since the 1990s, rhEPO has been successfully used to treat chronic kidney disease (CKD)-related anemia, but a

\footnotetext{
*Correspondence: peter.radermacher@uni-ulm.de

'Sektion Anästhesiologische Pathophysiologie, Klinik für Anästhesiologie,

Universitätsklinikum, Helmholtzstrasse 8-1, 89081 Ulm, Germany

Full list of author information is available at the end of the article
}

subset of approximately $10 \%$ of these patients does not adequately respond to rhEPO therapy [6]. This condition is referred to as 'EPO resistance,' which is characterized by either a need for higher doses of EPO to maintain the recommended hemoglobin $(\mathrm{Hb})$ or even a lack of response to EPO at all [6]. The conflicting results of the recent clinical trials that evaluated the cytoprotective effects of rhEPO beg the question of the applicability of our preclinical models in the clinical setting. The following viewpoint uses rhEPO as an example to highlight the possible pitfalls in current practice using young healthy animals for the evaluation of therapies to treat patients of variable age and underlying chronic co-morbidity.

\section{Erythropoietin and its receptor}

While EPO is mainly produced in the peri-tubular cells of the kidney in response to hypoxia, low levels of $E P O$ mRNA have also been reported in the central nervous system, lungs and spleen. EPO is well-known as a regulator of erythrocyte production to optimize tissue oxygenation: A drop in local $\mathrm{O}_{2}$ tension leads to the stabilization of hypoxia inducible factor, which binds to the hypoxia-responsive elements of the EPO gene activating its transcription. EPO needs a receptor (EPO-R) to perform its function, and this EPO-R is expressed on erythroid cell progenitors and in a variety of tissues and cell types - for example, the brain, retina, heart, kidney, vascular smooth muscle cells, myoblasts and vascular endothelium. Administration of EPO upregulates EPO- $\mathrm{R}$ expression and increases endothelial nitric oxide (NO) production. EPO-R expression was also confirmed in primary human kidney tubular epithelial cells, in rat cortical and medullary tubules as well as in porcine wound healing fluid, granulation tissue, and kidney [7-9]. However, children with acute kidney injury presented with elevated EPO-R expression in the kidney but decreased EPO plasma levels [10], and differential regulation of EPO-R expression in renal tissue biopsies from young, healthy versus older, co-morbid swine was reported [11].

Accruing evidence suggests that EPO exerts tissueprotective properties via a different heteroreceptor 
EPO-R isoform, which has been proposed to comprise a classic EPO-R homodimer and the cytokine $\beta$-common receptor $(\beta c R)$. Gorio and colleagues [12] demonstrated both the association of the $\beta c R$ subunit and the EPO-R as well as the need for the heteroreceptor combination for the recovery of motor function after spinal cord compression injury. Saqib and colleagues [9] showed in a porcine model of wound healing that EPO was associated with an increase of granulation tissue, and demonstrated higher expression and the co-localization of EPO-R and $\beta c R$ in the cellular constituents of the granulation tissue. It is noteworthy that the $\beta c R$ is involved in EPO-mediated endothelial nitric oxide synthase (eNOS) activation in endothelial cells [13]: both EPO- and eNOS-derived NO inhibit neo-intima formation and improve re-endothelialization in a dose-dependent manner [14]. Furthermore, synthetic EPO derivatives like carbamylated EPO (cEPO) provided additional insight into the properties of the EPO hetero-receptor complex: cEPO does not bind to the hematopoietic EPO-R and thus does not increase the hematocrit, but exerted cytoprotective effects in cerebral infarction, spinal cord trauma, and kidney ischemia/ reperfusion (I/R) injury [15]. Recently, cEPO was even reported to more effectively reduce kidney inflammation in brain-dead rats than rhEPO [16], and a newly developed cEPO-FC fusion protein was at least as protective as rhEPO in a porcine aortic balloon occlusion-induced spinal cord I/R injury [17]. At present, four clinical trials have evaluated the safety and pharmacokinetics of cEPO for acute ischemic stroke (ClinicalTrials.gov identifiers NCT00870844 and NCT00756249), in advanced kidney cancer (NCT00035243) as well as in patients with the Friedreich's ataxia (NCT01016366): so far results are not yet available.

\section{Erythropoietin pre-clinical studies}

The first tissue-protective effects of EPO were observed in animal models of ischemic injury in the brain and spinal cord. Later reports followed of EPO's protective role in models of myocardial infarction, where it apparently has a very large range of applicability: before ischemia, acutely during reperfusion and even after myocardial ischemia. In all these conditions, chronic administration led to a reduction of myocardial injury and remodeling. In rodent [15,16,18-27], large animal [17,27-41] and primate [42] models, EPO protected against $I / R$ injury in the central nervous system $[17,26,27]$, the heart $[20,21,29-37]$, and the kidney [2226,38-42]. Tables 1 to 3 present major pre-clinical studies documenting the tissue-protective effects of EPO in rodent and large animal models. It is interesting to note that in the majority of these studies, EPO had more pronounced therapeutic effects in rodents than in large animal models. One porcine study even reported that
EPO failed to exert any cardioprotective effect [29]. Clearly, the less efficacy in large animals may be due to the lack of resuscitative measures in small animal experiments. Nonetheless, the pleiotropic effects of EPO are well-established in many pre-clinical studies, through the use of commercially available rhEPO, synthetic EPO derivatives or mimetic peptide analogs such as ARA-290. Therefore, let us now take a look at the recent clinical trials.

\section{Erythropoietin clinical trials}

Corwin and coleagues' report on the CRIT Study [43] examined the incidence of anemia and red blood cell transfusions in critically ill patients and determined that trauma patients were more likely to be transfused than non-trauma patients. Four separate randomized, placebocontrolled studies using rhEPO in this context were conducted, which enrolled 160,1,302, and 1,460 anemic (total $\mathrm{Hb}$ concentration of $<12 \mathrm{~g} \mathrm{dL}^{-1}$ ) critically ill patients [44-46] and 86 'long-term acute care patients' [47]. The first two trials demonstrated a reduction of transfusion requirements, and the second even had an increased survival rate in the treatment arm. Due to a lack of data of specific trauma events that could affect the outcome, however, a definitive assessment was impossible. Interestingly, in the third trial no transfusion reduction was observed with treatment despite the increase in $\mathrm{Hb}$ content. Furthermore, there was a clinically significant increase in thrombovascular events in rhEPO-treated patients in comparison to vehicle $[44,45]$. Finally, the most recent long-term trauma outcome study evaluating the role of rhEPO in anemic $\left(\mathrm{Hb}<12 \mathrm{~g} \mathrm{dL}^{-1}\right)$ trauma subjects found no differences in physical function or safety between the treatment and control arms [46].

Ehrenreich and colleagues [48] showed promising neuroprotective effects of rhEPO in a pilot study of ischemic stroke. The subsequent large double-blind, placebo-controlled, randomized muticenter rhEPO stroke trial not only failed to show any neuroprotective benefit, but, contrary to all expectations, patients treated both with rhEPO and tissue plaminogen activator presented with increased intracerebral hemorrhage and mortality [49]. Yip and colleagues [50] also tried to assess the benefits of rhEPO after acute ischemic stroke: they reported an increase in endothelial progenitor cells and decrease of 90-day major adverse neurological events. The commentary by Minnerup and colleagues [51] highlighted the fact that the two trials focused on different primary endpoints: a reduced incidence of recurrent strokes at day 90 does not necessarily imply improved neurological function.

The two trials on EPO effects on spinal cord injury, Evaluation of Tolerability and Efficacy of EPO Therapy in Spinal Shock (NCT00220675) and EPO Spinal Cord 
Table 1. Pre-clinical data on effects of rhEPO and cEPO in models of central nervous (cerebral and spinal cord) I/R injury

\begin{tabular}{|c|c|c|c|c|c|c|c|}
\hline Species & Model & Dose (IU.kg-1) & Protocol & Outcome & Histology & Apoptosis & Reference \\
\hline Rat & $\begin{array}{l}\text { Stroke: embolic } \\
\text { middle cerebral } \\
\text { artery occlusion }\end{array}$ & $\begin{array}{l}500,1,150 \\
\text { or } 5,000\end{array}$ & $\begin{array}{l}6,24 \text {, and } 48 \mathrm{~h} \\
\text { post-embolus }\end{array}$ & $\begin{array}{l}50 \% \text { improvement of } \\
\text { foot-fault test and modified } \\
\text { Neurological Severity Score }\end{array}$ & $\begin{array}{l}\text { Dose-dependent } \\
\text { reduction of infarct } \\
\text { volume }(17,28,36 \%) \text {; } \\
3 \% \text { reduction in } \\
\text { activated microglial } \\
\text { cells }\end{array}$ & $\begin{array}{l}31 \% \text { drop in TUNEL } \\
\text { cells }\end{array}$ & [18] \\
\hline Rat & $\begin{array}{l}\text { Stroke: left } \\
\text { internal carotid } \\
\text { artery occlusion }\end{array}$ & 5,000 & $\begin{array}{l}\text { Immediately, } \\
12 \text {, and } 24 \mathrm{~h} \\
\text { after ischemia }\end{array}$ & $\begin{array}{l}20 \% \text { improved 'corner test'; } \\
\text { reduced oxidative stress } \\
\text { and inflammation }\end{array}$ & $\begin{array}{l}\text { Reduced infarct } \\
\text { size ( } 7 \text { versus } \\
\text { 25\%); enhanced } \\
\text { angiogenesis }\end{array}$ & $\begin{array}{l}50 \% \text { drop in TUNEL } \\
\text { cells; increased Bcl } \\
\text { expression }\end{array}$ & [19] \\
\hline Swine & $\begin{array}{l}\text { Aortic balloon } \\
\text { occlusion spinal } \\
\text { cord ischemia/ } \\
\text { reperfusion injury }\end{array}$ & $\begin{array}{l}5,000 \\
\text { CEPO-FC } \\
50 \mu \mathrm{g} \cdot \mathrm{kg}^{-1}\end{array}$ & $\begin{array}{l}30 \text { minutes } \\
\text { before, over } 4 \mathrm{~h} \\
\text { after ischemia }\end{array}$ & $\begin{array}{l}\text { Improved lower limb } \\
\text { neurological function } \\
\text { (response score: vehicle 0, } \\
\text { rhEPO 4, cEPO-FC 4) and } \\
\text { motor evoked potentials } \\
\text { (vehicle 0, rhEPO 10, cEPO- } \\
\text { FC 63\% recovery); reduced } \\
\text { oxidative stress (blood } \\
\text { isoprostane levels) }\end{array}$ & $\begin{array}{l}\text { Less NISSL-positive } \\
\text { neurons (thoracic: } \\
\text { vehicle 27, rhEPO } 5 \\
\text { cEPO-FC 8\%; lumbar: } \\
\text { vehicle 26, rhEPO 8, } \\
\text { cEPO-FC 7\%) }\end{array}$ & $\begin{array}{l}\text { No TUNEL and } \\
\text { caspase-3-positive } \\
\text { neurons }\end{array}$ & [17] \\
\hline Swine & $\begin{array}{l}\text { Hypothermic } \\
\text { circulatory arrest }\end{array}$ & 500 & $\begin{array}{l}60 \text { minutes } \\
\text { before cardiac } \\
\text { arrest }\end{array}$ & $\begin{array}{l}\text { No difference in mortality } \\
\text { or neurological outcome; } \\
\text { lower glutamate and } \\
\text { glycerol levels (cerebral } \\
\text { microdialysis) }\end{array}$ & $\begin{array}{l}\text { No difference in brain } \\
\text { histology }\end{array}$ & $\begin{array}{l}\text { Apoptotic index } \\
\text { (TUNEL) } 0.0 \text { versus } \\
0.99\end{array}$ & [27] \\
\hline Swine & $\begin{array}{l}\text { Deep } \\
\text { hypothermic } \\
\text { circulatory arrest }\end{array}$ & 500 & $\begin{array}{l}24 \text { and } 3 \mathrm{~h} \\
\text { before, } 24 \mathrm{~h} \\
\text { after cardiac } \\
\text { arrest }\end{array}$ & $\begin{array}{l}\text { No difference in mortality } \\
\text { or neurological outcome; } \\
\text { lower S-100ß, lactate, and } \\
\text { glycerol levels (cerebral } \\
\text { microdialysis) }\end{array}$ & $\begin{array}{l}\text { No difference in } \\
\text { histology; reduced } \\
\text { brain infarction ( } 2 / 8 \\
\text { versus } 8 / 8)\end{array}$ & ND & [28] \\
\hline Swine & $\begin{array}{l}\text { Aortic balloon } \\
\text { occlusion spinal } \\
\text { cord ischemia/ } \\
\text { reperfusion injury }\end{array}$ & 300 & $\begin{array}{l}30 \text { minutes } \\
\text { before, over } 4 \mathrm{~h} \\
\text { after ischemia }\end{array}$ & $\begin{array}{l}\text { No differences in motor } \\
\text { evoked potentials }\end{array}$ & $\begin{array}{l}\text { Less NISSL-positive } \\
\text { neurons in thoracic } \\
\text { ( } 25 \text { versus 38\%) spinal } \\
\text { cord, lumbar spinal } \\
\text { cord no difference }\end{array}$ & $\begin{array}{l}\text { Thoracic spinal } \\
\text { cord: less TUNEL } \\
\text { cells (18 versus } 65 \text { ); } \\
\text { lumbar spinal cord: } \\
\text { no difference }\end{array}$ & [39] \\
\hline
\end{tabular}

CEPO, carbamylated erythropoietin; I/R, ischemia/reperfusion; ND, not determined; rhEPO, recombinant human erythropoietin; TUNEL, terminal deoxynucleotidyl transferase dUTP nick end labeling.

Compression Randomized Trial (NCT00220675) were both terminated prematurely. An additional trial looking at the benefits of rhEPO without prophylactic anticoagulation in elective spinal surgery noted an increase in deep vein thrombotic events. The study concludes with the recommendation to add anti-thrombotic prophylaxis to rhEPO in the surgical setting [52].

The Reduction of Infarct Expansion and Ventricular Remodeling with Erythropoietin after Large Myocardial Infarction (REVEAL) trial enrolled 222 patients and showed unchanged infarct size after treatment compared to vehicle. Interestingly, in the treatment arm, older patients (aged $>70$ years) even presented with a doubling in infarct size in the first week [53].

In the setting of acute kidney injury (AKI) a study of 71 patients undergoing elective coronary artery bypass graft surgery had a reno-protective effect [54], whereas the larger $(n=162)$ Early Intervention in Acute Renal Failure
(EARLYARF) trial, evaluating rhEPO therapy in a heterogeneous group of ICU patients, found no such effects [55]. Another clinical trial (Recombinant Human Erythropoietin use in Intensive Care Unit Patients: Does it prevent acute renal failure; NCT00676234) recruited 80 patients and was completed in 2009 , but no data are available so far. Finally, a very recent follow-up report from the aforementioned trial [55] on the incidence of end-stage renal disease and mortality showed that rhEPO reduced all-cause mortality and development of endstage renal disease in patients that had previously suffered from AKI [56]. This subset of patients with AKI comprised 21 patients, 14 in the placebo group and 7 in the rhEPO group. Interestingly, patients in the placebo group were older (67 to 84 years; 10 of the 14 patients were $>70$ years) than those in the rhEPO group (58 to 75 years; 3 of the 7 were $>70$ years). It may be too early to make definitive conclusions from these data, but the 
Table 2. Pre-clinical data on effects of rhEPO and EPO analogs in models of myocardial I/R injury

\begin{tabular}{|c|c|c|c|c|c|c|c|}
\hline Species & Model & Dose (IU.kg-1) & Protocol & Outcome & Histology & Apoptosis & Reference \\
\hline Rat & $\begin{array}{l}\text { Coronary artery } \\
\text { ligation }\end{array}$ & 8,000 & $\begin{array}{l}\text { Immediately, or } \\
3 \text { weeks after } \\
\text { artery ligation, } \\
\text { once a week } \\
\text { over } 3 \text { weeks }\end{array}$ & $\begin{array}{l}\text { Decrease in LVDEP by } \\
27 \text { to } 38 \% \text {, improved } \\
\text { contractility and } \\
\text { relaxation, no difference } \\
\text { in mortality }\end{array}$ & $\begin{array}{l}\text { Early treatment: } \\
\text { reduced infarct } \\
\text { size ( } 23 \text { to } 30 \%) ; \\
\text { late treatment: } \\
\text { no difference, but } \\
\text { increased capillary } \\
\text { density (39 to 48\%) }\end{array}$ & ND & {$[20]$} \\
\hline Mouse & $\begin{array}{l}\text { Coronary artery } \\
\text { ligation }\end{array}$ & 2,500 & $\begin{array}{l}24 \mathrm{~h} \text { and } 30 \\
\text { minutes before, } \\
\text { or immediately } \\
\text { after ligation }\end{array}$ & $\begin{array}{l}\text { nNOS-dependent } \\
\text { reduction of ventricular } \\
\text { arrhythmia }\end{array}$ & $\begin{array}{l}50 \% \text { reduction of } \\
\text { infarct size }\end{array}$ & ND & [21] \\
\hline Swine & $\begin{array}{l}\text { Coronary artery } \\
\text { occlusion }\end{array}$ & 500 & $\begin{array}{l}24 \text { h and } 90 \\
\text { minutes, or } 90 \\
\text { minutes alone } \\
\text { before ischemia }\end{array}$ & $\begin{array}{l}\text { No cardioprotective } \\
\text { effects }\end{array}$ & $\begin{array}{l}\text { Infarct size not } \\
\text { different }\end{array}$ & ND & [29] \\
\hline Dog & $\begin{array}{l}\text { Coronary artery } \\
\text { ligation }\end{array}$ & 1,000 & $\begin{array}{l}\text { Immediately, } \\
6 \mathrm{~h} \text {, or } 1 \text { week } \\
\text { after ischemia }\end{array}$ & $\begin{array}{l}\text { Less ventricular fibrillation } \\
\text { during reperfusion (0 } \\
\text { versus 50\%) }\end{array}$ & $\begin{array}{l}\text { Reduced infarct size } \\
\text { (8 versus 40\%) }\end{array}$ & Less TUNEL cells (50\%) & {$[30]$} \\
\hline Dog & $\begin{array}{l}\text { Coronary artery } \\
\text { ligation }\end{array}$ & 1,000 & $\begin{array}{l}\text { Bolus } \\
\text { immediately, } \\
6 \mathrm{~h} \text {, or } 1 \text { week } \\
\text { after ischemia }\end{array}$ & $\begin{array}{l}\text { Increase in LVEF ( } 42 \text { versus } \\
\text { 49/56\%), improved } \\
\text { capillary density and } \\
\text { myocardial blood flow } \\
\text { (by 50\%) }\end{array}$ & $\begin{array}{l}\text { Reduced infarct size } \\
\text { (10 versus18\%) }\end{array}$ & ND & [31] \\
\hline Swine & $\begin{array}{l}\text { Chronic } \\
\text { myocardial } \\
\text { ischemia }\end{array}$ & 300 & $\begin{array}{l}\text { Endocardial } \\
\text { injection } \\
2 \text { weeks } \\
\text { after start of } \\
\text { ischemia }\end{array}$ & $\begin{array}{l}\text { LVEF } 64 \text { versus 55\%; } \\
2.2 \text { versus } 3.3 \text { hypokinetic } \\
\text { segments }\end{array}$ & $\begin{array}{l}\text { Reduced ischemic } \\
\text { surface ( } 19 \text { versus } \\
41 \%) \text {, less fibrosis } \\
\text { (8 versus } 27 \%)\end{array}$ & ND & {$[32]$} \\
\hline Swine & $\begin{array}{l}\text { Coronary artery } \\
\text { occlusion }\end{array}$ & $\begin{array}{l}\text { Darbepoitein } \\
30{\mathrm{\mu g} \cdot \mathrm{kg}^{-1}}^{-1}\end{array}$ & $\begin{array}{l}\text { At time of } \\
\text { reperfusion }\end{array}$ & $\begin{array}{l}\text { Regional functional } \\
\text { improvement }\end{array}$ & $\begin{array}{l}\text { No reduction in } \\
\text { infarct size, less } \\
\text { fibrosis ( } 7 \text { versus 10\%); } \\
\text { increased capillary } \\
\text { density (106 versus } \\
89 \%)\end{array}$ & ND & [33] \\
\hline Swine & $\begin{array}{l}\text { Chronic } \\
\text { myocardial } \\
\text { ischemia }\end{array}$ & 300 & $\begin{array}{l}\text { Endocardial } \\
\text { injection } \\
2 \text { weeks } \\
\text { after start of } \\
\text { ischemia }\end{array}$ & $\begin{array}{l}\text { LVEF } 66 \text { versus } 55 \% \text {; } \\
2.2 \text { versus } 3.3 \text { hypokinetic } \\
\text { segments }\end{array}$ & $\begin{array}{l}\text { Less fibrosis } 8 \text { versus } \\
27 \%\end{array}$ & $\begin{array}{l}\text { TUNEL cells not } \\
\text { detected }\end{array}$ & {$[34]$} \\
\hline Swine & $\begin{array}{l}\text { Coronary artery } \\
\text { occlusion }\end{array}$ & $\begin{array}{l}\text { EPO analog } \\
0.9 / 0.4 \mu \mathrm{\mu g} \cdot \mathrm{kg}^{-1}\end{array}$ & $\begin{array}{l}\text { At time of } \\
\text { reperfusion, } \\
\text { once weekly } \\
\text { over } 4 \text { weeks }\end{array}$ & $\begin{array}{l}\text { LVEF } 39 \text { versus 33\%; } \\
\text { improved wall motion } \\
\text { score }\end{array}$ & $\begin{array}{l}\text { Less fibrosis } 7 \text { versus } \\
12 \%, 50 \% \text { increase in } \\
\text { peri-infarct capillary } \\
\text { density, infarct size not } \\
\text { different }\end{array}$ & ND & {$[35]$} \\
\hline Swine & $\begin{array}{l}\text { Coronary artery } \\
\text { ligation }\end{array}$ & 500 & $\begin{array}{l}30 \text { minutes } \\
\text { and } 24 \mathrm{~h} \text { after } \\
\text { ischemia }\end{array}$ & $\begin{array}{l}\text { Fractional shortening } \\
55 \text { versus } 36 \% \text { at day 14; } \\
\text { reduced oxidative stress } \\
\text { and enhanced eNOS } \\
\text { expression }\end{array}$ & $\begin{array}{l}25 \% \text { reduction of } \\
\text { infarct size; enhanced } \\
\text { angiogenesis }\end{array}$ & $\begin{array}{l}\text { Less TUNEL cells } \\
\text { (50\%), less caspase-3 } \\
\text { expression }\end{array}$ & {$[36]$} \\
\hline Swine & $\begin{array}{l}\text { Coronary artery } \\
\text { embolization }\end{array}$ & 200 & $\begin{array}{l}\text { Every } 2 \text { days } \\
\text { over } 8 \text { days }\end{array}$ & $\begin{array}{l}\text { Cardiac function not } \\
\text { different; increased VEGF } \\
\text { and angiogenesis }\end{array}$ & $\begin{array}{l}\text { Infarct size and fibrosis } \\
\text { not different }\end{array}$ & ND & {$[37]$} \\
\hline
\end{tabular}


Table 3. Pre-clinical data on effects of rhEPO and cEPO in models of kidney I/R injury

\begin{tabular}{|c|c|c|c|c|c|c|c|}
\hline Species & Model & Dose $\left(I U \cdot k^{-1}\right)$ & Protocol & Outcome & Histology & Apoptosis & Reference \\
\hline Rat & $\begin{array}{l}\text { Bilateral renal } \\
\text { artery occlusion }\end{array}$ & 300 & $\begin{array}{l}30 \text { minutes } \\
\text { before } \\
\text { ischemia, or } \\
5 \text { minutes } \\
\text { before, or } \\
30 \text { minutes } \\
\text { after start of } \\
\text { reperfusion }\end{array}$ & $\begin{array}{l}\text { Less rise in creatinine }(150 \\
\left.\text { to } 170 \text { versus } 220 \mu \mathrm{mol} \cdot \mathrm{L}^{-1}\right) \\
\text { and higher creatinine } \\
\text { clearance }(0.3 \text { versus } \\
\left.<0.1 \mathrm{ml} \cdot \text { minute }^{-1}\right) ;\end{array}$ & $\begin{array}{l}50 \% \text { lower } \\
\text { histopathology score }\end{array}$ & $\begin{array}{l}\text { Less TUNEL cells } \\
(50 \%) \text {, less caspase-3 } \\
\text { expression }\end{array}$ & [22] \\
\hline Mouse & $\begin{array}{l}\text { Bilateral renal } \\
\text { artery occlusion }\end{array}$ & 1,000 & $\begin{array}{l}\text { Daily over } \\
3 \text { days or } \\
\text { immediately } \\
\text { before } \\
\text { ischemia }\end{array}$ & $\begin{array}{l}\text { Less rise in urea and } \\
\text { creatinine (pre-treatment: } \\
200 \text { versus } 350 / 0.8 \\
\text { versus } 2.0 \mathrm{mg} \cdot \mathrm{dL}^{-1} ; \\
\text { pre-reperfusion: } 300 \\
\text { versus } 350 / 1.5 \text { versus } \\
2.0 \mathrm{mg} \cdot \mathrm{dL}^{-1} \mathrm{mg} \cdot \mathrm{dL}^{-1} \text { ); } \\
\text { attenuated tissue } \\
\text { inflammation and lipid } \\
\text { peroxidation }\end{array}$ & $\begin{array}{l}\text { Reduced tubular } \\
\text { dilatation, swelling } \\
\text { and necrosis }\end{array}$ & ND & [23] \\
\hline Rat & $\begin{array}{l}\text { Unilateral renal } \\
\text { artery occlusion }\end{array}$ & 5,000 & $\begin{array}{l}30 \text { minutes } \\
\text { before } \\
\text { ischemia }\end{array}$ & $\begin{array}{l}\text { Lower serum creatinine } \\
\left(0.04 \text { versus } 0.21 \mathrm{mmol} \cdot \mathrm{L}^{-1}\right) \\
\text { and urea }(13 \text { versus } 41 \\
\left.\text { mmol. } \mathrm{L}^{-1}\right) \text {; enhanced } \\
\text { tubular regeneration }\end{array}$ & $\begin{array}{l}\text { Ameliorated tubular } \\
\text { cast formation }\end{array}$ & $\begin{array}{l}\text { Less ascending limb } \\
\text { apoptosis ( } 2.2 \text { versus } \\
6.5 \%)\end{array}$ & [24] \\
\hline Rat & $\begin{array}{l}\text { Bilateral renal } \\
\text { artery occlusion }\end{array}$ & 500 & $\begin{array}{l}20 \text { minutes } \\
\text { before } \\
\text { ischemia }\end{array}$ & 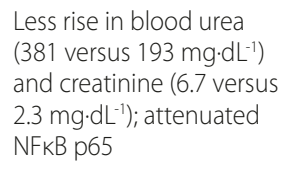 & $\begin{array}{l}50 \% \text { reduction of } \\
\text { tubular necrosis }\end{array}$ & $\begin{array}{l}\text { Less TUNEL positive } \\
\text { cells, less Bax } \\
\text { expression }\end{array}$ & [25] \\
\hline Rat & $\begin{array}{l}\text { Bilateral renal } \\
\text { artery occlusion }\end{array}$ & 5,000 & $\begin{array}{l}\text { At time of } \\
\text { ischemia (T0), } \\
\text { or } 6 \text { h post- } \\
\text { ischemia (T6) }\end{array}$ & $\begin{array}{l}\text { Less rise in serum } \\
\text { creatinine }(T(0): 0.04 \\
\text { versus } 0.17, T(6): 0.03 \\
\left.\text { versus } 0.17 \mathrm{mmol} \cdot \mathrm{L}^{-1}\right) ; 2 \text { - to } \\
\text { 3-fold higher mitosis in } \\
\text { cortex and outer medulla }\end{array}$ & $\begin{array}{l}\text { Reduced tubular } \\
\text { luminal casts, no } \\
\text { attenuation of } \\
\text { necrosis }\end{array}$ & $\begin{array}{l}50 \text { to } 70 \% \text { less TUNEL } \\
\text { cells }\end{array}$ & [26] \\
\hline Swine & $\begin{array}{l}\text { Renal artery } \\
\text { occlusion after } \\
\text { nephrectomy }\end{array}$ & 1,000 & $\begin{array}{l}\text { At time of } \\
\text { ischemia, daily } \\
\text { over } 5 \text { days of } \\
\text { reperfusion }\end{array}$ & $\begin{array}{l}\text { Ameliorated creatinine } \\
\text { clearance at } 12 \text { h: } 95 \\
\text { versus 68/74\% at } 12 \text { and } \\
36 \mathrm{~h}\end{array}$ & Less necrotic cells & $\begin{array}{l}\text { Less caspase-3 } \\
\text { positive tubular cells }\end{array}$ & [38] \\
\hline Swine & $\begin{array}{l}\text { Aortic balloon } \\
\text { occlusion }\end{array}$ & 300 & $\begin{array}{l}30 \text { minutes } \\
\text { before } \\
\text { occlusion, over } \\
\text { for } 4 \text { h during } \\
\text { reperfusion }\end{array}$ & $\begin{array}{l}\text { Improved creatinine } \\
\text { clearance }(66 \text { versus } \\
48 \mathrm{ml} \cdot \text { minute }{ }^{-1} \text { ) and lower } \\
\text { fractional } \mathrm{Na} \text { excretion } \\
\text { (8 versus } 12 \% \text { ) }\end{array}$ & Histology not different & TUNEL not different & [39] \\
\hline Swine & $\begin{array}{l}\text { Unilateral renal } \\
\text { artery occlusion }\end{array}$ & 5,000 & $\begin{array}{l}1 \mathrm{~h} \text { before } \\
\text { clamping }\end{array}$ & $\begin{array}{l}\text { Less ( } 25 \text { versus } 75 \% \text { ) fall in } \\
\text { glomerular filtration rate, } \\
\text { no difference in fractional } \\
\text { Na excretion }\end{array}$ & ND & $\begin{array}{l}\text { No difference in } \\
\text { caspase-3 }\end{array}$ & [41] \\
\hline Primate & $\begin{array}{l}\text { Unilateral renal } \\
\text { artery occlusion }\end{array}$ & 2,400 & $\begin{array}{l}5 \text { minutes } \\
\text { each before } \\
\text { clamping and } \\
\text { declamping }\end{array}$ & $\begin{array}{l}\text { Lower creatinine, urea, } \\
\text { and cystatin C ( } 7 \text { versus } \\
3,60 \text { versus } 40,1.8 \\
\left.\text { versus } 2.5 \mathrm{mg} \cdot \mathrm{dL}^{-1}\right) \text {; lower } \\
\text { IL-6 levels ( } 50 \text { versus } \\
100 \mathrm{pg} \cdot \mathrm{L}^{-1} \text { ) }\end{array}$ & $\begin{array}{l}\text { Ameliorated } \\
\text { congestion, cell } \\
\text { infiltration }\end{array}$ & $\begin{array}{l}\text { Less tubular TUNEL } \\
\text { cells }\end{array}$ & [42] \\
\hline
\end{tabular}


REVEAL study suggests putative harm by rhEPO in patients aged over 70 years [53]. Whether or not age (and the presence or not of underlying CKD) may provide useful information defining who may be best served by rhEPO therapy warrants further investigation.

\section{Chronic kidney disease and erythropoietin resistance}

In an effort to understand why results from recent clinical trials to treat AKI are mixed, let us take a look at renal disease and CKD-related co-morbidity and EPO resistance. Renal disease is associated with a graded increase in both inflammatory and oxidative markers: i) patients with CKD presented with increased blood lipid hydroperoxide, oxidized low density lipoproteins, F2-isoprostanes, TNF- $\alpha$, IL- 6 , and IFN- $\gamma$ when compared with patients with normal kidney function [6,57]; ii) in subgroup studies from clinical trials, patients with CKD responded differently to pharmaceutical interventions compared to patients with normal kidney function [58]; iii) atherosclerosis, which is characterized by an increase in low density lipoproteins, a decrease in high density lipoproteins, oxidative stress, endothelial dysfunction and inflammation, is prevalent in CKD, increases with age, and is the main risk factor for cardiovascular disease [57]. Finally, atherosclerosis is also associated with reduced NO bioavailability [59], and the constitutive production of NO has been shown to be attenuated in patients with CKD [60].

The mechanisms underlying EPO resistance are poorly understood and most likely multi-factorial, since endogenous EPO levels tend to be higher in these patients than in control subjects [61]. Age and the manifold aspects of ageing add to this complexity: in a geriatric cohort higher EPO blood levels were directly related to mortality [6]. Nevertheless, there is general consensus that inflammation and oxidative stress are key players $[6,62,63]$ : the pro-inflammatory cytokines IL-6, IFN- $\gamma$, and TNF- $\alpha$ may antagonize the actions of EPO by inhibiting erythroid progenitor cells, activating suppressor of cytokine signaling, down-regulating EPO-R expression and generating reactive oxygen species that lead to lipid peroxidation of red cell membranes $[6,62,63]$. Moreover, EPO activates eNOS, which is considered to be critical for its tissue protective effects: genetic eNOS deletion is associated with a loss of response of endothelial progenitor cells to EPO stimulation ex vivo [64], and in vivo EPO not only failed to exert any vasoprotective effects but even worsened remodeling after vascular injury [59]. In rats with heminephrectomyinduced polycythemia, EPO aggravated arterial hypertension and only partially attenuated the fall of the glomerular filtration rate caused by non-selective NO synthase inhibition with L-NAME ( ${ }^{G}$-nitro-L-argininemethyl ester) [65].

\section{Animal models}

Animal models that use young and healthy animals are essential for the understanding of basic pathophysiological mechanisms. Any investigator will try to reduce inter-individual variation as much as possible and choose animals of the same sex, age and strain in order to control for physiology and establish reproducible and defined conditions. Such models are valuable inasmuch as they provide unique insights into the pathophysiology of specific experimental scenarios and even identify novel therapeutic targets. However, one of the problems with research conducted in naive animals is that a dramatic benefit is often observed that cannot be reproduced in the clinical study: a systemic review of pre-clinical and clinical trials concluded that the discordance was due, at least in part, to the failure in the pre-clinical trial to properly mimic the clinical disease [66]. A single factor such as age may have major effects: antibiotic therapy in cecal ligation puncture-induced murine sepsis halved mortality in young animals, while this intervention had no benefit in older mice [67]. In contrast to the epidemiology in patients, who usually present with variable co-morbidity, all data on EPO-related organ protection against $I / R$ injury originate from models investigating young and healthy animals. This limitation thus assumes importance in light of failed clinical studies in comparison to pre-clinical trials. We found a similar lack of protection against I/R injury of rhEPO in adult swine with ubiquitous atherosclerosis resulting from familial hypercholesteremia [11] and an atherogenic diet (socalled familial hypercholesteremia Bretoncelles Meishian (FMB) swine) when compared to otherwise young and healthy animals $[17,39]$. These FBM swine present with hypercholesteremia and increased markers of oxidative stress, while creatinine clearance, blood levels of NO metabolites, and renal tissue expression of EPO-R are reduced - that is, this strain shows a biomarker pattern comparable with that found in patients with hypercholesteremia-induced atherosclerosis $[11,68]$. As agematched wild-type and young (6 months) FBM swine without the atherogenic diet showed the same EPO-R expression as young and healthy animals, the reduced EPO-R expression may not only provide a plausible explanation for ineffectiveness of EPO in this model, but also potentially hint at one of the underlying causes of 'EPO resistance'.

\section{Conclusion}

The promise of pre-clinical data on organ-protective effects of rhEPO has not been matched by successful clinical trials. The results from the animal models using young, healthy animals provide us with very important pathophysiological mechanistic information. The mechanisms may apply, but often other factors, including 
gender, age, and, in particular, co-morbidity, confound the therapeutic strategy. The distinct contrast in the experimental results in kidney $I / R$ injury between the young, healthy swine and the FBM swine might help to underline the importance of pre-existing co-morbid conditions for the design of pre-clinical experimental models. These results may not only offer a potential explanation for the differing results of receptor expression in human samples, which may be reconciled when the etiology of disease of the donors are better understood, but also suggest that animal models that more closely mimic the human disease conditions may provide better guidance for future therapeutic strategies. Finally, it is tempting to speculate whether pre-existing impairment of kidney function and decreased renal tissue EPO-R expression may explain the controversial effects of rhEPO in clinical trials.

\section{Abbreviations}

$\beta c R$, cytokine $\beta$-common receptor; $A K l$, acute kidney injury; $C E P O$, carbamylated erythropoietin; CKD, chronic kidney disease; CRIT, Anemia and blood transfusion in the critically ill-current clinical practice in the United States; EARLYAF, Early Intervention in Acute Renal Failure; eNOS, endothelial (constitutive) nitric oxide synthase; EPO, erythropoietin; EPO-R, erythropoietin receptor; FBM, familial hypercholesteremia Bretoncelles Meishian; $\mathrm{Hb}$, hemoglobin; IFN, interferon; IL, interleukin; I/R, ischemia/reperfusion; NO, nitric oxide; REVEAL, Reduction of Infarct Expansion and Ventricular Remodeling with Erythropoietin after Large Myocardial Infarction; rhEPO, recombinant human erythropoietin; $\mathrm{TNF}$, tumor necorosis factor.

\section{Competing interests}

PR received research funding from Polymun Scientific $\mathrm{GmbH}$ (Klosterneuburg, Austria), a company involved in the commercial development of CEPO-FC. The other authors declare that they have no competing interests.

\section{Author details}

'Sektion Anästhesiologische Pathophysiologie, Klinik für Anästhesiologie, Universitätsklinikum, Helmholtzstrasse 8-1, 89081 Ulm, Germany. ${ }^{2}$ Abteilung Pathologie, Universitätsklinikum, Albert-Einstein-Allee 23, 89081 Ulm, Germany. ${ }^{3}$ Centre for Translational Medicine and Therapeutics, William Harvey Research Institute, Charterhouse Square, London EC1M 6BQ, United Kingdom.

Published: 26 September 2012

\section{References}

1. Moore E, Bellomo R: Erythropoietin (EPO) in acute kidney injury. Ann Intensive Care 2011, 1:3

2. Patel NS, Collino M, Yaqoob MM: Erythropoietin in the intensive care unit: beyond treatment of anemia. Ann Intensive Care 2011, 1:40.

3. Patel NSA, Nandra KK, Thiemermann C: Bench-to-bedside review: Erythropoietin and its derivatives as therapies in critical care. Crit Care 2012, 16:229.

4. Ghezzi P, Bernaudin M, Bianchi R, Blomgren K, Brines M, Campana W, Cavaletti G, Cerami A, Chopp M, Coleman T, Digicaylioglu M, Ehrenreich H, Erbayraktar S, Erbayraktar Z, Gassmann M, Genc S, Gokmen N, Grasso G, Juul S, Lipton SA, Hand CC, Latini R, Lauria G, Leist M, Newton SS, Petit E, Probert L, Sfacteria A, Siren AL, Talan M, et al:: Erythropoietin: not just about erythropoiesis. Lancet 2010, 375:210

5. Goldsmith D: Extraordinary popular delusions and the madness of crowds: puncturing the epoietin bubble - lessons for the future. Nephrol Dial Transplant 2011, 26:24-28.

6. Bamgbolla OF: Patterns of resistance to erythropoietin-stimulating agents in chronic kidney disease. Kidney Int 2011, 80:464-474.

7. De Beuf M, Verhulst A, Helbert M: Tubular erythropoietin receptor expression mediates erythropoietin-induced renoprotection. Open Hematol J 2009, 3:1-10
8. Elliott S, Busse L, Swift S, McCaffery I, Rossi J, Kassner P, Begley CG: Lack of expression and function of erythropoietin receptors in the kidney. Nephrol Dial Transplant 2011, 27:2733-2745.

9. Saqib M, Duling L, Krier K, Howdieshell TR: Temporal and spatial expression of erythropoietin, erythropoietin receptor and common $\beta$ receptor in wound fluid and granulation tissue. Wounds 2009, 21:164-171.

10. Li Z, Hui T, Xun M, Duan C, Zhang Y, Yin Y, Din Y, Zhang L: Expression of erythropoietin and erythropoietin receptor on renal tissue in children with acute kidney injury (abstract). Pediatr Res 2011, 70:765.

11. McCook O, Simon F, Matějková S, J Matallo, A Scheuerle, P Moeller, M Georgieff, E Calzia, P Radermacher, H Schelzig: Reduced EPO receptor expression may contribute to limited pleitropic effects of EPO during critical illness. Critical Care 2012, 16 (Suppl 1):P440.

12. Gorio A, Gokmen N, Erbayraktar S, Yilmaz O, Madaschi L, Cichetti C, Di Giulio AM, Vardar E, Cerami A, Brines M: Recombinant human erythropoietin counteracts secondary injury and markedly enhances neurological recovery from experimental spinal cord trauma. Proc Natl Acad Sci U S A 2002, 99:9450-9455.

13. Su KH, Shyue SK, Kou YR, Ching LC, Chiang AN, Yu YB, Chen CY, Pan CC, Lee TS: $\beta$ Common receptor integrates the erythropoietin signaling in activation of endothelial nitric oxide synthase. J Cell Physio/ 2011, 226:3330-3339.

14. Urao N, Okigaki M, Yamada H, Aadachi Y, Matsuno K, Matsui A, Matsunaga S, Tateishi K, Nomura T, Takahashi T, Tatsumi T, Matsubara H: Erythropoietinmobilized endothelial progenitors enhance reendothelialization via Aktendothelial nitric oxide synthase activation and prevent neointimal hyperplasia. Circ Res 2006, 98:1405-1413.

15. Leist M, Ghezzi P, Grasso G, Bianchi R, Villa P, Fratelli M, Savino C, Bianchi M, Nielsen J, Gerwien J, Kallunki P, Larsen AK, Helboe L, Christensen S, Pedersen LO, Nielsen M, Torup L, Sager T, Sfacteria A, Erbayraktar S, Erbayraktar Z, Gokmen N, Yilmaz O, Cerami-Hand C, Xie QW, Coleman T, Cerami A, Brines M: Derivatives of erythropoietin that are tissue protective but not erythropoietic. Science 2004, 305:239-242

16. Nijboer W, Ottens P, van Dijk A, van Goor H, Ploeg RJ, Leuvenink HG: Donor pretreatment with carbamylated erythropoietin in a brain death model reduces inflammation more effectively than erythropoietin while preserving renal function. Crit Care Med 2010, 38:1156-1161.

17. Simon F Scheuerle A, Gröger M, Vcelar B, McCook O, Möller P, Georgieff M, Calzia E, Radermacher P, Schelzig H: Comparison of carbamylated fusion and recombinant human erythropoietin during porcine aortic balloon occlusion-induced spinal cord ischemia/reperfusion injury. Intensive Care Med 2011, 37:1525-1533.

18. Wang Y, Zhang ZG, Rhodes K, Renzi M, Zhang RL, Kapke A, Lu M, Pool C, Heavner G, Chopp M: Post-ischemic treatment with erythropoietin or carbamylated erythropoietin reduces and improves neurological outcome in a rat model of focal cerebral ischemia. Br J Pharmacol 2007, 151:1377-1384.

19. Yuen CM, Leu S, Lee FY, Yen CH, Lin YC, Chua S, Chung SY, Chai HT, Sheu JJ, Ko SF, Sun CK, Yip HK: Erythropoietin markedly attenuates brain infarct size and improves neurological function in the rat. J Invest Med 2010, 58:893-904.

20. van der Meer P, Lipsic E, Henning RH, Boddeus K, van der Velden J, Voors AA, van Veldhuisen DJ, van Gilst WH, Schoemaker RG: Erythropoietin induces neovascularization and improves cardiac function in rats with heart failure after myocardial infarction. J Am Coll Cardio/ 2005, 46:125-133.

21. Burger DE, Xiang FL, Hammoud L, Jones DL, Feng Q: Erythropoietin protects the heart from ventricular arrhythmia during ischemia and reperfusion via neuronal nitric-oxide synthase. J Pharmac Exp Ther 2009, 329:900-907.

22. Sharples EJ, Patel N, Brown P, Stewart K, Mota-Philipe H, Sheaff M, Kieswich J, Allen D, Harwood S, Raftery M, Thiemermann C, Yaqoob MM: Erythropoietin protects the kidney against injury and dysfunction caused by ischemiareperfusion. J Am Soc Nephrol 2004, 15:2115-2124.

23. Patel NSA, Sharples EJ, Cuzzocrea S, Chatterjee PK, Britti D, Yaqoob MM, Thiemermann C: Pretreatment with EPO reduces the injury and dysfunction caused by ischemia/reperfusion in the mouse kidney in vivo. Kidney Int 2004, 66:983-989.

24. Vesey DA, Cheung C, Pat B, Endre Z, Gobé G, Johnson DW: Erythropoietin protects against ischemic acute renal injury. Nephrol Dial Transplant 2004, 19:348-355.

25. Spandou E, Tsouchnikas I, Karkavelas G, Dounousi E, Simeonidou C, GuibaTziampiri O, Tsakiris D: Erythropoietin attenuates renal injury in experimental acute renal failure ischaemic/reperfusion model. Nephrol 
Dial Transplant 2006, 21:330-336.

26. Johnson DW, Pat B, Vesey DA, Guan Z, Endre Z, Gobé GC: Delayed administration of darbeboietin or erythropoietin protects against ischemic acute renal injury and failure. Kidney Intern 2006, 69:1806-1813.

27. Romsi P, Rönka E, Kiviluoma K, Vainionpää V, Hirvonen J, Mennander A, Pokela $M$, Biancari F, Rimpiläinen J, Juvonen T: Potential neuroprotective benefits of erythropoietin during experimental hypothermic circulatory arrest. J Thorac Cardiovasc Surg 2002, 124:714-723.

28. Givehchian M, Beschorner R, Ehmann C, Frauenlob L, Morgalla M, Hashemi B, Ziemer G, Scheule AM: Neuroprotective effects of erythropoietin during deep hypothermic circulatory arrest. Eur J Cardio-Thorac Surg 2010, 37:662-668

29. Kristensen J, Maeng M, Rehling M, Berg JS, Mortensen UM, Nielsen SS, Nielsen TT: Lack of acute cardioprotective effect preischaemic erythropoietin administration in a porcine coronary occlusion model. Clin Physiol Funct Imaging 2005, 25:305-310

30. Hirata A, Minamino T, Asanuma H, Sanada S, Fujita M, Tsukamoto O, Wakeno M, Myoishi M, Okada K, Koyama H, Komamura K, Takashima S, Shinozaki Y, Mori H, Tomoike H, Hori M, Kitakaze M: Erythropoietin just before reperfusion reduces both lethal arrhythmias and infarct size via the phosphatidylinositol-3 kinase-dependent pathway in canine hearts. Cardiovasc Drugs Ther 2005, 19:33-40.

31. Hirata A, Minamino T, Asanuma H, Fujita M, Wakeno M, Myoishi M, Tsukamoto O, Okada K, Koyama H, Komamura K, Takashima S, Shinozaki Y, Mori H, Shiraga M, Kitakaze M, Hori M: Erythropoietin enhances neovascularization of ischemic myocardium and improves left ventricular dysfunction after myocardial infarction in dogs. J Am Coll Cardiol 2006, 48:176-184.

32. Krause KT, Jaquet K, Geidel S, Schneider C, Mandel C, Stoll HP, Hertting K, Harle T, Kuck KH: Percutaneous endocardial injection of erythropoietin: assessment of cardioprotection by electromechanical mapping. Eur $J$ Heart Fail 2006, 8:443-450

33. Toma C, Letts DP, Tanabe M, Gorcsan J 3rd, Counihan PJ: Positive effect of darbepoetin on peri-infarction remodeling in a porcine model of myocardial ischemia-reperfusion. J Mol Cell Cardiol 2007, 43:130-136.

34. Schneider C, Jaquet K, Malisius R, Geidel S, Bahlmann E, Boczor S, Rau T, Antz $\mathrm{M}$, Kuck KH, Krause K: Attenuation of cardiac remodeling by endocardial injection of erythropoietin: ultrasonic strain-rate imaging in a model of hibernating myocardium. European Heart J 2007, 28:499-509.

35. Angeli FS, Amabile N, Burjonroppa S, Shapiro M, Bartlett L, Zhang Y, Virmani R, Chatterjee K, Boyle A, Grossman W, Yeghiazarians Y: Prolonged therapy with erythropoietin is safe and prevents deterioration of left ventricular systolic function in a porcine model of myocardial infarction. J Cardiac Failure 2010, 16:579-589

36. Chua S, Leu S, Lin YC, Sheu JJ, Sun CK, Chung SY, Chai HT, Lee FY, Kao YH, Wu CJ, Chang LT, Ko SF, Yip HK: Early erythropoietin therapy attenuates remodeling and preserves function of left ventricle in porcine myocardial infarction. J Invest Med 2010, 59:574-586.

37. Kawachi K, Iso Y, Sato T, Wakabayashi K, Kobayashi Y, Takeyama Y, Suzuki H: Effects of erythropoietin on angiogenesis after myocardial infarction in porcine. Heart Vessels 2012, 27:79-88

38. Forman CJ, Johnson DW, Nicol DL: Erythropoietin administration protects against functional impairment and cell death after ischaemic renal injury in pigs. BJU Int 2006, 9:162-165.

39. Simon F, Scheuerle A, Calzia E, Bassi G, Öter S, Duy CN, Kick J, Brückner UB, Radermacher P, Schelzig H: Erythropoietin during porcine aortic balloon occlusion-induced ischemia/reperfusion injury. Crit Care Med 2008, 36:2143-2150

40. Maio R, Sepodes B, Patel NS, Thiemermann C, Mota-Filipe H, Costa P: Erythropoietin preserves the integrity and quality of organs for transplantation after cardiac death. Shock 2011, 35:126-133.

41. Sølling C, Christensen AT, Krag S, Frøkiaer J, Wogensen L, Krog J, Tønnesen EK: Erythropoietin administration is associated with short term improvement in glomerular filtration rate after ischemia reperfusion injury. Acta Anaesthesiol Scand 2011, 55:185-195.

42. Ishii Y, Sawada T, Murakami T, Sakuraoka Y, Shiraki T, Shimizu A, Kubota K, Fuchinoue S, Teraoka S: Renoprotective effect of erythropoietin against ischemia-reperfusion injury in a non-human primate model. Nephrol Dial Transplant 2011, 26:1157-1162.

43. Corwin HL, Gettinger A, Pearl RG, Fink MP, Levy MM, Abraham E, Maclntyre NR, Shabot MM, Duh MS, Shapiro MJ: The CRIT Study: Anemia and blood transfusion in the ciritically ill - current clinical practice in the United
States. Crit Care Med 2004, 32:39-52.

44. Corwin HL, Gettinger A, Pearl RG, Fink MP, Levy MM, Shapiro MJ, Corwin MJ, Colton T; EPO Critical Care Trials Group: Efficacy of recombinant human erythropoietin in critically ill patients. JAMA 2002, 288:2827-2835.

45. Napolitano LM, Fabian TC, Kelly KM, Bailey JA, Block EF, LangholffW, Enny C, Corwin HL: Improved survival of critically ill patients treated with recombinant human erythropoietin. J Trauma 2008, 65:285-299.

46. Luchette FA, Pasquale MD, Fabian TC, LangholffWK, Wolfson M: A randomized, double blind, placebo-controlled study to assess the effect of recombinant human erythropoietin on functional outcomes in anemic, critically ill, trauma subjects: the Long Term Trauma Outcomes Study. Am Surg 2012, 203:508-516.

47. Silver M, Corwin MJ, Bazan A, Gettinger A, Enny C, Corwin HL: Efficacy of recombinant human erythropoietin in critically ill patients admitted to a long-term acute care facility: a randomized, double-blind, placebocontrolled trial. Crit Care Med 2006, 34:2310-2316

48. Ehrenreich H, Hasselblatt M, Dembowski C, Cepek L, Leczuk P, Stiefle M, Rustenbeck HH, Breiter N, Jacob S, Knerlich F, Bohn M, Poser W, Rüther E, Kochen M, Gefeller O, Gleiter C, Wessel TC, De Ryck M, Itri L, Prnage H, Ceram A, Brines M, Sirén AL: Erythropoietin therapy for acute stroke is both safe and beneficial. Mol Med 2002, 8:495-505.

49. Ehrenreich $H$, Weissenborn K, Prange H, Schneider D, Weimar C, Wartenberg K, Schellinger PD, Bohn M, Becker H, Wegrzyn M, Jähnig P, Herrmann M, Knauth M, Bähr M, Heide W, Wagner A, Schwab S, Reichmann H, Schwendemann G, Dengler R, Kastrup A, Bartels C, for the EPO Stroke Trial Group: Recombinant human erythropoietin in the treatment of acute ischemic stroke. Stroke 2009, 40:e647-e656

50. Yip HK, Tsai TH, Lin HS, Chen SF, Sun CK, Leu S, Yuen CM, Tan TY, Lan MY, Liou CW, Lu CH, Chang WN: Effect of erythropoietin on level of circulating endothelial progenitor cells and outcome in patients after acute ischemic stroke. Crit Care 2011, 15:R40.

51. Minnerup J, Wersching H, Schäbitz WR: Erythropoietin for stroke treatment: dead or alive? Crit Care 2011, 15:129.

52. Stowell CP, Jones SC, Enny C, LangholffW, Leitz G: An open label, randomized, parallel-group study of perioperative epoietin alfa versus standard of care for blood conservation in major elective spinal cord surgery. Spine 2009, 34:2479-2485.

53. Naijar SS, Rao SV, Melloni C, Raman SV, Povsic TJ, Melton L, Barsness GW, Prather K, Heitner JF, Kilaru R, Gruberg L, Hasselblad V, Greenbaum AB, Patel M, Kim RJ, Talan M, Ferrucci L, Longo DL, Lakatta EG, Harrington RA; REVEAL Investigators: Intravenous erythropoietin in patients with ST-segment elevation myocardial infarction. JAMA 2011, 305:1863-1872.

54. Song YS, Lee T, You SJ, Chin HJ, Chae DW, Lim C, Park KH, Han S, Kim JH, Na KY: Prevention of acute kidney injury by Erythropoietin in patients undergoing coronary artery bypass grafting: a pilot study. Am J Nephrol 2009, 30:253-260.

55. Endre ZH, Walker RJ, Pickering JW, Shaw GM, Frampton CM, Henderson SJ, Hutchison R, Mehrtens JE, Robinson JM, Schollum JB, Westhuyzen J, Celi LA, McGinley RJ, Campbell IJ, George PM: Early intervention with erythropoietin does not affect the outcome of acute kidney injury (the EARLYARF trial). Kidney Int 2010, 77:1020-1030.

56. Oh SW, Chin HJ, Chae DW, Na KY: Erythropoietin improves long-term outcomes in patients with acute kidney injury after coronary artery bypass grafting. J Korean Med Sci 2012 27:506-511.

57. Cachofeiro V, Goicochea M, García de Vinuesa S, Oubiña P, Lahera V, Luño J: Oxidative stress and inflammation, a link between chronic kidney disease and cardiovascular disease. Kidney Int 2008, 74(Suppl 111):S4-S9.

58. Jun M, LV J, Perkovic V, Jardine MJ: Managing cardiovascular risk in people with chronic kidney disease: a review of the evidence from randomized controlled trials. Ther Adv Chronic Dis 2011, 2:265-278.

59. d'Uscio LV, Smith LA, Santhanam AV, Richardson D, Nath Ka, Katusic ZS: Essential role of endothelial nitric oxide synthase in vascular effects of erythropoietin. Hypertension 2007, 49:1142-1148.

60. Wever R, Boer P, Hijmering M, Verhaar M, Kastelein J, Versluis K, Lagerwerf F, van Rijn H, Koomans H, RabelinkT: Nitric oxide production is reduced in patients with chronic renal failure. Arterioscler Thromb Vasc Biol 1999, 19:1168-1172.

61. Weiner DE, Miskulin DC: Anemia managment in chronic kidney disease: bursting the hemoglobin bubble. Ann Intern Med 2010, 153:53-55.

62. Stenvinkel P, Bárány P: Anaemia, rHuEPO resistance, and cardiovascular disease in end-stage renal failure: links to inflammation and oxidative 
stress. Nephrol Dial Transplant 2002, 17(Suppl 5):32-37.

63. van der Putten K, Braam B, Yie KE, Gaillard CA: Mechanisms of disease: erythropoietin resistance in patients with both heart and kidney failure. Nat Clin Pract Nephrol 2008, 4:47-57.

64. Santhanam AV, d'Uscio LV, Peterson TE, Katusic ZS: Activation of endothelial nitric oxide synthase is critical for erythropoietin-induced mobilization of progenitor cells. Peptides 2008, 29:1451-1455.

65. Kawata T, Hashimoto S, Koike T: Effects of chronic nitric oxide synthase inhibition on renal function and histology in polycythemic rats. Kidney Blood Press Res 1998, 21:22-28

66. Perel P, Roberts I, Sena E, Wheble P, Briscoe C, Sandercock P, Macleod M, Mignini LE, Jayaram P, Khan KS: Comparison of treatment affects between animal experiments and clinical trials: systemic review. BMJ 2007, 334:197.
67. Turnbull IS, Wizorek JJ, Osborne D, Hotchkiss RS, Coopersmith CM, Buchman TG: Effects of age on mortality and antibiotic efficacy in cecal ligation and puncture. Shock 2003, 19:310-313.

68. Kawashima S, Yokoyama M: Dysfunction of endothelial nitric oxide synthase and atherosclerosis. Arterioscler Thromb Vasc Biol 2004, 24:998-1005.

\section{doi:10.1186/cc11430}

Cite this article as: $\mathrm{McCook} \mathrm{O}$, et al: Erythropoietin in the critically ill: do we ask the right questions? Critical Care 2012, 16:319. 